\title{
THE DIET OF WESTERN BURROWING OWLS IN AN URBAN LANDSCAPE
}

\author{
Lynne A. Trulio ${ }^{1,2}$ and Philip Higgins ${ }^{1}$
}

\begin{abstract}
While we know much about the diet of Western Burrowing Owls (Athene cunicularia hypugaea) in many of their more natural habitats, little is known about their diets in urban environments. We analyzed pellets and prey remains collected at burrows used by Burrowing Owls living in urban grasslands in Santa Clara County, California. We hypothesized that the composition of prey species in the diet of these urban owls would differ from that of owls living in agricultural and more-natural western habitats and, in particular, that rodents would be a smaller component of the diet. We found the invertebrate-to-vertebrate ratio to be approximately $94: 6$ by number. Orthoptera, Dermaptera, and Coleoptera were the most abundant invertebrate orders, while rodents accounted for $70 \%$ of the estimated biomass per burrow of all orders. This overall composition and these taxa are typical for Burrowing Owls in western habitats. However, Botta's pocket gopher (Thomomys bottae) was an important prey species by biomass, a species not often recorded as a dominant prey item of owls living in western habitats. The California vole (Microtus californicus) and house mouse (Mus musculus) were also dominant prey items by biomass. We recommend managing Western Burrowing Owl habitat for species, especially rodents such as pocket gophers and voles, that do well in urban habitats.
\end{abstract}

Resumen.-A pesar de saber mucho acerca del régimen alimenticio del tecolote llanero occidental (Athene cunicularia hypugaea) en muchos de sus hábitats más naturales, poco se sabe acerca de su dieta en ambientes urbanos. Analizamos las bolas de hueso, pelo y plumas que vomitan los tecolotes y los restos de presas colectados en las madrigueras habitadas por los tecolotes llaneros que viven en las praderas urbanas del condado de Santa Clara, California. Planteamos la hipótesis de que la composición de las especies de presas que conforman la dieta de estos tecolotes urbanos diferiría de la de los tecolotes que viven en hábitats agrícolas y más naturales de la región occidental, y en particular, que los roedores serían un componente más pequeño de su dieta. Descubrimos que la proporción de invertebrados a vertebrados es aproximadamente 94:6 por números. Orthoptera, Dermaptera y Coleoptera fueron los órdenes de invertebrados más abundantes, mientras que, de todas las órdenes de animales, los roedores componen el $70 \%$ del número estimado de biomasa por madriguera. Esta composición en general y estos taxa son característicos de los tecolotes llaneros en hábitats occidentales. Pero la tuza de Botta (Thomomys bottae) fue una especie de presa importante por biomasa, una especie que pocas veces se ha observado como una presa principal de los tecolotes que viven en hábitats occidentales. La rata de campo californiana (Microtus californicus) y el ratón doméstico (Mus musculus) también fueron presas principales por biomasa. Recomendamos manejar el hábitat de los tecolotes llaneros para las especies que prosperan en hábitats urbanos, especialmente los roedores tales como las tuzas y ratas de campo.

Grasslands across North America have been significantly reduced; they are some of the most threatened and degraded habitats on the continent (Jones and Bock 2002). Grassland avifaunas are known to be sensitive to changes in their grassland communities (Jones and Bock 2002), and many bird species, such as the Western Burrowing Owl (Athene cunicularia hypugaea), are experiencing population declines and challenging habitat conditions throughout their range (Holroyd et al. 2001).

Western Burrowing Owls are found in open habitat with sufficient prey and burrows (Haug et al. 1993, Green and Anthony 1997), including human-altered habitats such as urban parks, airports, and agricultural areas; the owls are even found adjacent to residential and com- mercial areas (Haug et al. 1993, Millsap and Bear 2000, Trulio and Chromczak 2007). Western Burrowing Owls living in urban settings face a number of challenges, including impacts to prey species. While prey can maintain high densities with urbanization (Weseman and Rowe 1987, Blair 1996), important prey, such as rodents, are prone to population declines in fragmented habitats (Soulé et al. 1992), in proximity to urban/suburban edges (Bock et al. 2002), or in mowed grasslands (Adams 1984). Rodents play an important role in the breeding success of Burrowing Owls, and poor rodent availability can negatively affect productivity (Haley 2002, York et al. 2002, Rosenberg and Haley 2004).

The Western Burrowing Owl population in urban Santa Clara County, California, at the

\footnotetext{
${ }^{1}$ Department of Environmental Studies, San Jose State University, CA 95192-0115.

22E-mail: lynne.trulio@sjsu.edu
} 
south end of San Francisco Bay has experienced declines over the last 30 years (Buchanan 1996, Trulio and Chromczak 2007). The fate of this population may portend similar outcomes for other Burrowing Owl populations as urbanization spreads into Burrowing Owl habitat (Trulio and Chromczak 2007). While the loss of grasslands to urbanization is a major cause of owl declines (DeSante et al. 2004), availability of prey also likely plays a role. The diets of Western Burrowing Owls have been studied in natural areas (Green et al. 1993, Plumpton and Lutz 1993), agricultural areas (York et al. 2002, Rosenberg and Haley 2004, Moulton et al. 2005), and urban landscapes (Thomsen 1971, Weseman and Rowe 1987, Millsap and Bear 2000, Mrykalo et al. 2009). However, no study has characterized dietary composition of Western Burrowing Owls during breeding and nonbreeding seasons in a high-density, mixed land-use urban landscape. We hypothesized that the dominant prey species in the diet of urban Western Burrowing Owls in Santa Clara County would differ from owls living in agricultural or more-natural habitats, and in particular, that rodents would be a smaller component of the diet. We examined the dietary composition of Western Burrowing Owls to determine key taxa in the owls' diet for different seasons and under different land managements and to assess how diets differed from owls living in other habitats in the western United States.

\section{STUdy Area}

We collected pellets and prey remains from burrows at 5 grassland locations with documented Western Burrowing Owl nesting (Trulio and Chromzak 2007) located in Santa Clara County, California, at the south end of San Francisco Bay. The 5 study locations totaled approximately 1449.5 ha and ranged in size from 61.5 ha to 722.4 ha. Locations were delineated by the dominant land-management type, either park or nonpark land use, and by ownership boundary. This region has a mild Mediterranean climate with a rainy season from October to April and a dry season with nearly no rain from May to September. Both breeding and wintering Western Burrowing Owls are found in the study area.

All 5 study locations included or were adjacent to business districts, office parks, or resi- dential areas in which building plus pavement cover was approximately $80 \%, 65 \%$, and $45 \%$, respectively (Blair 1996). Building plus pavement cover for grasslands and golf courses within the study sites was 0\%-5\% (Blair 1996). Two study locations were on closed landfills managed as parks for passive recreation and wildlife use. The other 3, all nonpark land uses with a mix of private commercial and public land uses, consisted of grassland patches separated by developed features such as roads and buildings. Grasslands at all locations were dominated by nonnative grasses (predominantly Avena spp. and Hordeum spp.) and nonnative annuals, especially Salsola kali, Brassica spp., Picris echioides, and Dittrichia graveolens. Each location had irrigated turf for golf courses or playing fields.

\section{Methods}

We collected pellets and prey remains for 17 months, April 2005-August 2006, at the burrow entrances and perches used by nesting and nonnesting owls. All burrows were dug by California ground squirrels (Spermophilus beecheyi). The breeding season extended from 1 April to 31 August and spanned egg-laying through fledging; the nonbreeding season extended from 1 September to 31 March, when young-of-the-year disperse and adults migrate or move to other burrows. Specific pairs and single birds within breeding and nonbreeding seasons were reliably associated with particular burrows by regular observation conducted for this and other studies (Trulio and Chromczak 2007). Burrows (burrow mouths and perches) associated with particular birds within a season were considered independent of each other. They were used in statistical analyses of prey composition per burrow. Comparing park to nonpark burrows required aggregating burrows over the 3 seasons. Although not all burrows are independent from one season to the next, we assumed that approximately the same percentage of burrows in each land use were not independent in order to compare these 2 land-use types. Data from all burrow sites, including those that could not be associated with particular birds, were aggregated to provide an overall characterization of the dietary composition of birds in the area.

Active burrows were located in ruderal and irrigated grasslands using a walk-through 
transect survey method (Trulio and Chromczak 2007). During the 2005 breeding season, we collected all owl pellets and prey remains each week, such that on following visits only new pellets and prey remains were found. All pellets and prey remains collected on a specific date at a burrow constituted a "collection" for that burrow (Hall et al. 2009). During the 2006 breeding season, pellets and prey remains were collected every 2 weeks, and during the nonbreeding season, prey remains and pellets were collected once per month. Invertebrates in pellets and prey remains were identified to order (Powell and Hogue 1979). Vertebrates were identified using Jameson and Peeters (2004) and by comparing the specimens to those in the mammal collection at San Jose State University. Rodents, amphibians, and reptiles were identified to species where possible, while birds were not identified beyond class.

We combined the collections within a season for each burrow identified with an owl or owl pair. We determined the percent number of each taxon by dividing the number of individuals of that taxon by the total number of individuals collected for that burrow. We estimated the percent biomass per burrow for the 3 dominant invertebrate orders (Dermaptera, Coleoptera, and Orthoptera) and the 4 dominant vertebrate species, all rodents. We collected 20 individuals from each of the 3 dominant orders in the field using pitfall traps and sweep-net sampling (Higgins 2007). They were weighed upon capture, and the weights were used to estimate biomass. Rodent biomass was estimated, as per Jameson and Peeters (2004) and Kays and Wilson (2002), based on adult weights. Percent biomass was calculated as the biomass of a taxon per burrow, divided by the total biomass for that burrow.

We used SYSTAT $12{ }^{\circledR}$ (SYSTAT Software, Inc., Richmond, CA) to compare the prey composition by burrow, including only orders that composed $>1 \%$ and rodent species that composed $>0.1 \%$ of the total sample by number. We compared the percent number and percent biomass of prey per burrow between the 3 seasons using the Kruskal-Wallis test. We used the Mann-Whitney $U$ test to determine whether percent number or percent biomass of taxa per burrow differed for owls in park and nonpark land uses and to test whether the relative contribution of key rodent species differed by season or by land use.

\section{RESUlTS}

We collected a total of 3092 pellets and 83 prey items at 92 burrow sites, 54 of which could be associated with specific owl pairs or individuals. The 92 burrow sites yielded a total of 7227 individual prey items (pellets and remains) representing 11 orders/classes. The invertebrate-to-vertebrate ratio was 94:6. Three orders represented $92 \%$ of all prey items by total number: Dermaptera (earwigs, 48.6\%), Coleoptera (beetles, 27.5\%), and Orthoptera (grasshoppers, 16.0\%). Other invertebrate orders each composed $<1 \%$ of the diet (Stylommatophora, Isopoda, Araneae, Hymenoptera, Haplotaxa, Lepidoptera, Depapoda, and unidentified larvae). Vertebrates comprised 6\% of the diet by number, and 5 orders/classes were represented: Rodentia (5.5\%), Aves $(0.3 \%)$, Anura (Hyla regilla, <0.1\%), Squamata (Sceloporus occidentalis, 0.3\%), and Lagomorpha (Lepus californicus, $0.1 \%$ ). Rodent species found were Microtus californicus (1.9\%), Thomomys bottae (1.1\%), Mus musculus (1.1\%), Reithrodontomys megalotis (0.4\%), Peromyscus maniculatus $(<0.1 \%)$, and Spermophilus beecheyi $(<0.1 \%)$. Jackrabbits and California ground squirrels were only found as prey remains at the burrow entrances, apart from one juvenile ground squirrel found in a pellet.

Based on estimated biomasses for the 3 most common invertebrate orders (Dermaptera $=0.05 \mathrm{~g}$ per insect, Coleoptera $=0.25 \mathrm{~g}$ per insect, and Orthoptera $=3.32 \mathrm{~g}$ per insect) and the 4 most common vertebrate species (Microtus californicus [California vole] $=53.3$ $\mathrm{g}$ per individual, Mus musculus [house mouse] $=18.0 \mathrm{~g}$, Thomomys bottae [Botta's pocket gopher] = $155.5 \mathrm{~g}$, and Reithrodontomys megalotis [western harvest mouse] $=11.5 \mathrm{~g}$ ), vertebrates represented approximately $70 \%(\mathrm{SE}=$ 6.7) of the total biomass per burrow.

The percent number and percent biomass per burrow of the 4 dominant orders varied greatly among seasons (Table 1; Figs. la, 1b). Orthoptera numbers and biomass were higher in the breeding seasons and lower in the nonbreeding season; Dermaptera and Coleoptera showed the opposite pattern. Percent number per burrow of rodents was lowest in the nonbreeding season, but biomass per burrow was 

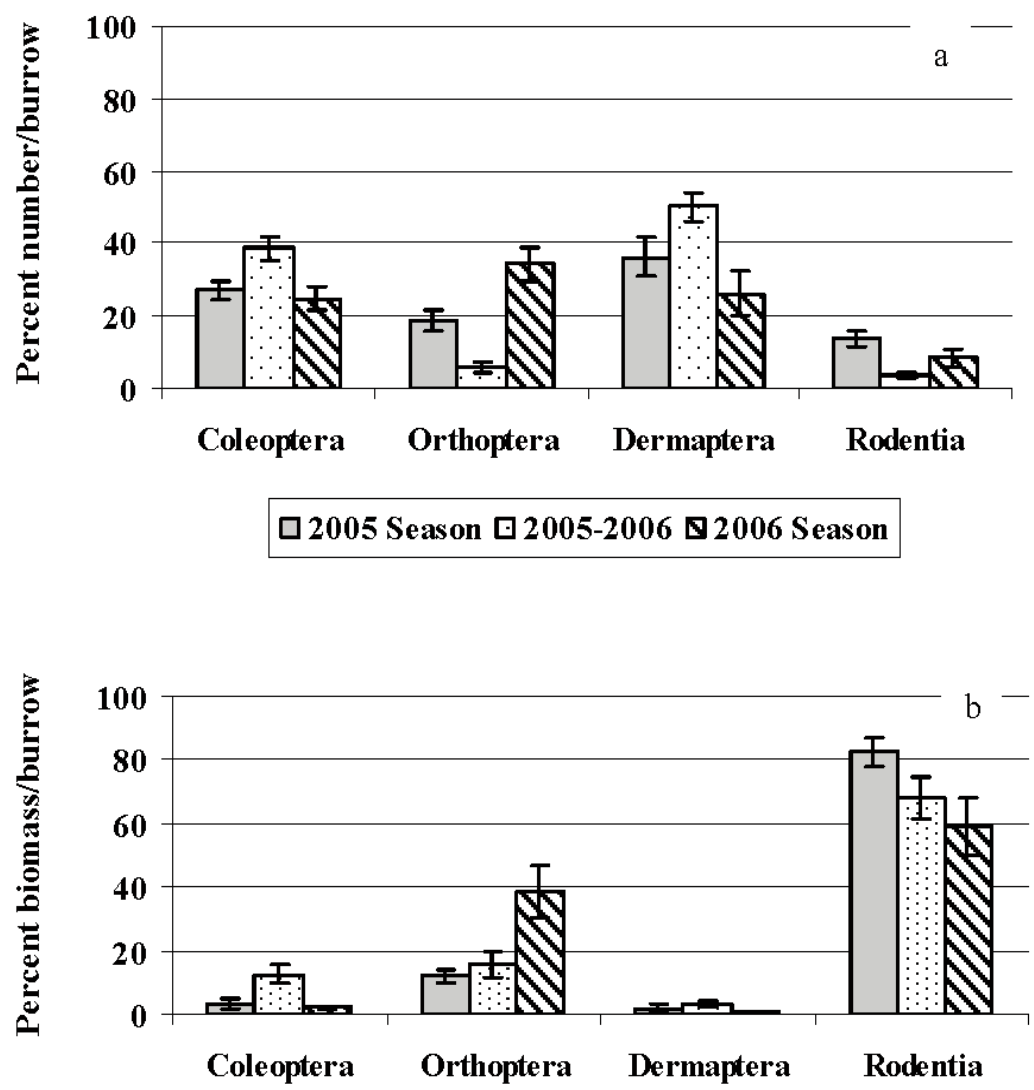

\section{$\square 2005$ Season $\square 2005-2006 \square 2006$ Seas on}

Fig. 1. Mean (SE) percent number (a) and percent biomass (b) per burrow of the 4 dominant orders of prey found in pellets and prey remains in 2 breeding seasons (2005 season: $n=22$; 2006 season: $n=18)$ and a nonbreeding season (2005-2006: $n=14)$, Santa Clara County, California, 2005-2006.

TABLE 1. Comparison (Kruskal-Wallis) of percent number and percent biomass per burrow of prey items found in pellets and prey remains for 3 seasons, 2 breeding seasons (2005 season: $n=22$; 2006 season: $n=18$ ), and a nonbreeding season (2005-2006: $n=14)$, Santa Clara County, California, 2005-2006.

\begin{tabular}{|c|c|c|c|c|}
\hline \multirow[b]{2}{*}{ Taxon } & \multicolumn{2}{|c|}{ Percent number } & \multicolumn{2}{|c|}{ Percent biomass } \\
\hline & KW score & $P$ value & KW score & $P$ value \\
\hline \multicolumn{5}{|l|}{ Order } \\
\hline Dermaptera & 7.525 & 0.023 & 15.726 & 0.000 \\
\hline Coleoptera & 9.019 & 0.011 & 18.034 & 0.000 \\
\hline Orthoptera & 22.213 & 0.000 & 5.662 & 0.059 \\
\hline Rodentia & 10.961 & 0.004 & 7.652 & 0.022 \\
\hline \multicolumn{5}{|l|}{ Species } \\
\hline Microtus californicus & 9.309 & 0.010 & 4.608 & 0.100 \\
\hline Mus musculus & 1.218 & 0.544 & 6.238 & 0.043 \\
\hline Thomomys bottae & 4.844 & 0.089 & 2.004 & 0.367 \\
\hline Reithrodontyomys megalotis & 7.071 & 0.029 & 5.302 & 0.071 \\
\hline
\end{tabular}




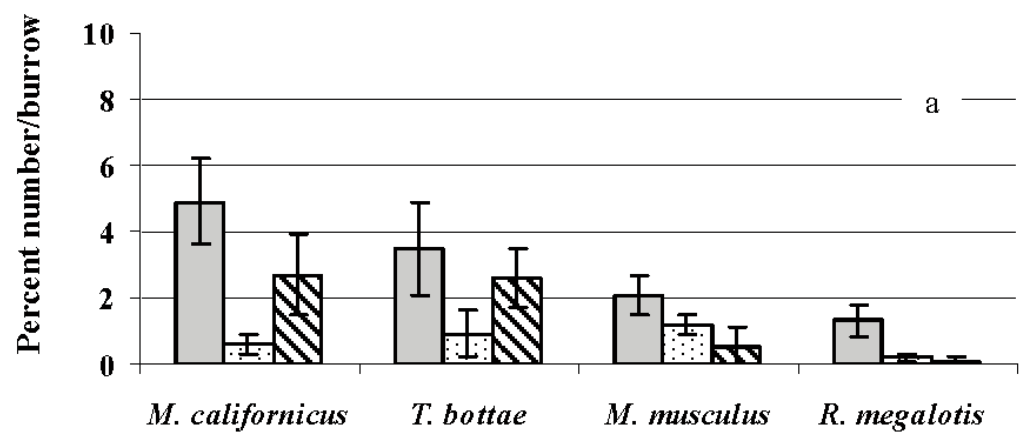

$\square 2005$ Seas on $\square 2005-2006 \square 2006$ Seas on

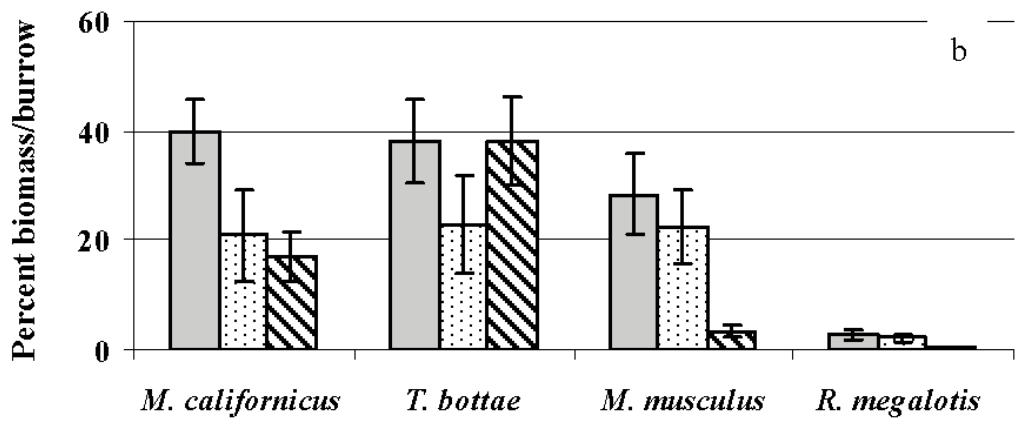

$\square 2005$ S eas on $\square 2005-2006 \square 2006$ Season

Fig. 2. Mean (SE) percent number (a) and percent biomass (b) per burrow of rodent prey found in pellets and prey remains in 2 breeding seasons (2005 season: $n=22 ; 2006$ season: $n=18)$ and a nonbreeding season $(2005-2006$ : $n=14)$, Santa Clara County, California, 2005-2006.

not appreciably lower in the nonbreeding season than in the breeding seasons. Botta's pocket gopher (T. bottae) and the California vole ( $M$. californicus) were the dominant rodents by percent number and percent biomass per burrow, and the house mouse (M. musculus) ranked third (Table 1; Figs. 2a, 2b).

In land-use comparisons (Table 2), percent numbers per burrow of Dermaptera were higher in nonpark locations, and percent numbers (though not biomass) of Rodentia appeared higher in park locations. Percent number and percent biomass per burrow of Mus musculus were higher in park than in nonpark land use, and T. bottae appeared to show the opposite pattern (Table 3; Fig. 3).

The percent biomass per burrow of the 2 dominant rodent species, T. bottae and M. cali- fornicus, did not differ among seasons (2005 breeding season: $n=22, Z=0.029, P=0.849$; nonbreeding 2005-2006: $n=14, Z=0.006, P$ $=0.979 ; 2006$ breeding season: $n=18, Z=$ $0.250, P=0.145)$ and did not differ between park locations $(n=23, Z=0.175, P=0.244)$. However, in nonpark locations, the percent biomass per burrow of $T$. bottae was somewhat greater than of $M$. californicus $(n=31, Z=$ 0.282, $P=0.030$; Fig. 3).

\section{Discussion}

Based on analysis of pellets and prey remains, invertebrates outnumbered vertebrates by 94:6 in the diet of urban Western Burrowing Owls in Santa Clara County. This composition of invertebrates and vertebrates is common in 
TABLE 2. Comparisons (Mann-Whitney $U$ ) of 2 land uses-park $(n=23)$ versus nonpark $(n=31)$-in percent number and percent biomass per burrow of prey items found in pellets and prey remains, Santa Clara County, California, 2005-2006. Means are given with SE in parentheses.

\begin{tabular}{|c|c|c|c|c|}
\hline Order/Class & Park & Nonpark & $Z$ score & $P$ value \\
\hline \multicolumn{5}{|l|}{ Percent number } \\
\hline Dermaptera & $27.2(3.9)$ & $43.1(4.4)$ & 0.321 & 0.022 \\
\hline Coleoptera & $32.3(2.6)$ & $27.1(2.4)$ & 0.210 & 0.128 \\
\hline Orthoptera & $24.7(3.9)$ & $17.7(3.2)$ & 0.208 & 0.132 \\
\hline Rodentia & $11.7(2.3)$ & $7.6(1.6)$ & 0.271 & 0.053 \\
\hline \multicolumn{5}{|l|}{ Percent biomass } \\
\hline Dermaptera & $1.5(0.5)$ & $2.1(0.9)$ & 0.171 & 0.217 \\
\hline Coleoptera & $5.2(1.4)$ & $5.4(1.7)$ & 0.008 & 0.951 \\
\hline Orthoptera & $19.2(3.6)$ & $23.8(5.5)$ & 0.092 & 0.501 \\
\hline Rodentia & $74.0(4.1)$ & $68.8(6.5)$ & 0.077 & 0.569 \\
\hline
\end{tabular}

TABle 3. Comparisons (Mann-Whitney $U$ ) of 2 land uses_park $(n=23)$ versus nonpark $(n=31)$ - in percent number and percent biomass of rodent species per burrow of prey items found in pellets and prey remains, Santa Clara County, California, 2005-2006. Means are given with SE in parentheses.

\begin{tabular}{|c|c|c|c|c|}
\hline Species & Park & Nonpark & $Z$ score & $P$ value \\
\hline \multicolumn{5}{|l|}{ Percent number } \\
\hline Microtus californicus & $4.8(1.5)$ & $1.8(0.5)$ & 0.191 & 0.164 \\
\hline Mus musculus & $2.1(0.4)$ & $1.4(0.5)$ & 0.343 & 0.016 \\
\hline Thomomys bottae & $2.1(0.8)$ & $2.8(1.0)$ & 0.169 & 0.220 \\
\hline Reithrodontyomys megalotis & $0.7(0.4)$ & $0.6(0.2)$ & 0.139 & 0.310 \\
\hline \multicolumn{5}{|l|}{ Percent biomass } \\
\hline Microtus californicus & $31.9(6.3)$ & $20.6(4.2)$ & 0.185 & 0.178 \\
\hline Mus musculus & $16.0(4.4)$ & $5.4(1.6)$ & 0.388 & 0.007 \\
\hline Thomomys bottae & $24.9(7.1)$ & $40.8(6.1)$ & 0.224 & 0.105 \\
\hline Reithrodontyomys megalotis & $1.2(0.5)$ & $2.0(0.7)$ & 0.153 & 0.264 \\
\hline
\end{tabular}

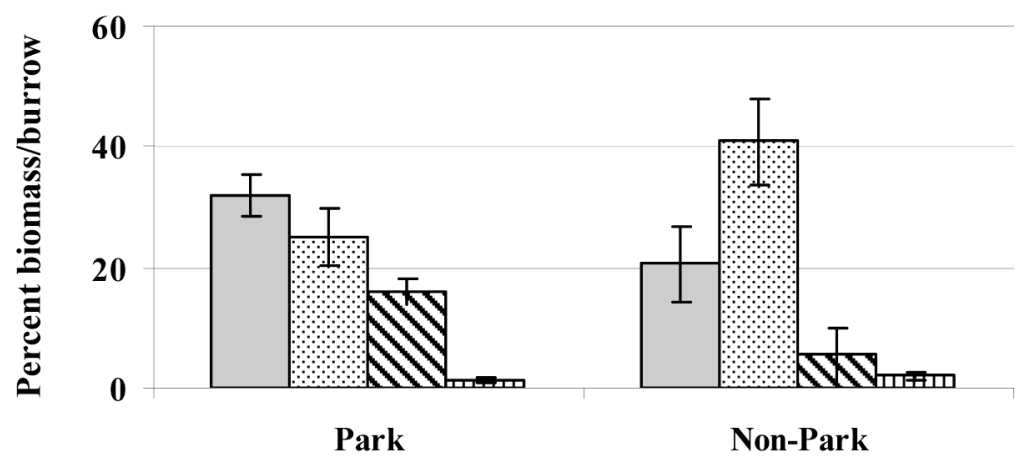

$\square$ M. californicus $⿴$ T. bottae $₫$ M. musculus $\square R$. megalotis

Fig. 3. Mean (SE) percent biomass per burrow of rodent prey found in pellets and prey remains for 2 land uses-park $(n=23)$ and nonpark $(n=31)$-Santa Clara County, California, 2005-2006.

owl populations in general (Poulin and Todd 2006) and in the western United States. For example, in Idaho (Gleason and Craig 1979, Moulton et al. 2005), Washington, and Oregon (Green et al. 1993), invertebrates composed approximately $90 \%-95 \%$ of all prey items in pellets collected in both agricultural and sagebrush/grassland habitats. However, Burrowing Owl diets vary based on local availability of prey (Haug et al. 1993). Thus, York et al. (2002) found the diet of Burrowing Owls in agricultural Imperial Valley, California, to be 
nearly $100 \%$ invertebrates (based on stomach contents), whereas Plumpton and Lutz (1993), working for 2 years in central Colorado, found approximately $50 \%$ of the prey items to be invertebrates.

In urban Santa Clara County, Orthoptera, Dermaptera, and Coleoptera were by far the dominant invertebrate orders by number. They were prevalent in both the breeding and nonbreeding season, as the area's mild climate supports year-round activity of these species; the seasonal variations were typical of these species in California (Coleoptera-Bolger et al. 2000; Orthoptera-Dingle et al. 1990; Dermaptera-Coulombe 1971). These orders are typically large components of Western Burrowing Owl diets in both agricultural and more-natural habitats. For example, in the agricultural Imperial Valley, Rosenberg and Haley (2004) reported that these 3 orders were the most frequent prey found in pellets. In Oregon and Washington sagebrush/disturbed grasslands (Green et al. 1993) and central California grasslands (Gervais et al. 2000), Coleoptera and Orthoptera were also prevalent species in pellets, as were spiders (Araneae). As in many other studies of Western Burrowing Owls (Gervais et al. 2000, Moulton et al. 2005, Hall et al. 2009), rodents were a major part of the owls' diets in Santa Clara County, composing over $70 \%$ of the biomass consumed. Rodents were important year-round (although less so in the winter nonbreeding season) for owls living on both park or nonpark land. Other vertebrates, such as birds (Rosenberg and Haley 2004) and reptiles (Hall et al. 2009), can be common prey, but they were not found to be important in the diet of the Santa Clara County birds.

We hypothesized that rodents would be a smaller component of the owls' diet in our study area compared to other western habitats. We did not see this difference, but we did see differences in the rodent species consumed. In particular, Botta's pocket gopher was a major component of owl diets in our study area in terms of percent biomass per burrow, both year-round and in different landuse types. This widely distributed rodent species has been recorded in numerous studies, but not often as a major dietary component for Western Burrowing Owls (Coulombe 1971, Thomson 1971, Rosenberg and Haley 2004, Hall et al. 2009; but see Gervais et al.
2000). Outside the range of T. bottae, $T$. talpoides (northern pocket gopher) appears as an important prey item for Burrowing Owls in sagebrush habitats in Idaho (Gleason and Johnson 1985) and in Oregon and Washington (Green et al. 1993).

Botta's pocket gophers do best in habitats with moist, friable, and disturbed soils where grasses and forbs are abundant (Jones and Baxter 2004). The study area had large irrigated spaces, such as those around buildings and on golf courses and playing fields, which promote pocket gopher populations. The greater estimated percent biomass per burrow of pocket gopher in nonpark locations in comparison to park sites may be due to different prey preferences by birds between the 2 land uses (Poulin and Todd 2006). An alternative explanation is that gophers were less abundant in park locations compared to nonpark sites. Such a difference may have resulted from the fact that the majority of the surface area of the 2 parks was on soil caps covering closed landfills. Landfill cap soil is typically a dense clay material designed to act as a barrier to prevent the escape of landfill material and gases (Handel et al. 1997). At park locations, this substrate or landfill cap grading may have inhibited pocket gopher burrowing activity.

Other prevalent rodent taxa found in diet studies of Western Burrowing Owls include Microtus, Peromyscus, Perognathus, and Dipodomys spp. In both agricultural areas (Gervais et al. 2000, Moulton et al. 2005) and sagebrush/grassland habitats in Colorado (Plumpton and Lutz 1993), Montana (Restani et al. 2001), and Idaho (Moulton et al. 2005), these rodent taxa were major components of owls' diets. In Santa Clara County, Microtus californicus and Mus musculus were the other large components of the rodent biomass in owl diets; both are abundant species that regularly inhabit human-altered environments. Explaining why $R$. megalotis and P. maniculatus, 2 common California rodents, were only marginally represented will require further study.

Urban settings present major challenges to rodent diversity and abundance due to habitat fragmentation (Bolger et al. 1997), land management such as mowing (Adams 1984), and proximity of urbanization (Bock et al. 2002). Increasing the availability of rodents, especially during the breeding season when avian species have large energy demands (Strong et 
al. 2004), can improve owl reproductive productivity (Haley 2002, Arana et al. 2006). Given the importance of California voles and Botta's pocket gophers in the diets of owls in this urban area, we recommend implementing landmanagement practices in Burrowing Owl habitat to support larger populations of these and other rodents that do well in urban landscapes.

\section{ACKNOWLEDGMENTS}

We thank the staff at our study locations including Cal Baker, Scott Libby, and Jean Replicon at Mission College; Chris Alderete at NASA Ames Research Center; Paula Bettencourt, Jack Smith, Steve Crane, and Brian Williams at Shoreline Park; William Theyskens and Silviana Ruiz at Sunnyvale Park; Dan Hammons at Sunnyvale Solid Waste Plant; and Mike Basil and Larry Wolfe at Santa Clara Golf and Tennis Club. Field assistance and equipment were provided by Debra Chromczak, Peggy Woodin, and Becky Brown of Mission College, Caitlin Bean of San Jose State University (SJSU), and Kristin Jensen Sullivan of DeAnza College. Dr. John Matson, Biological Science, SJSU, helped with rodent identification, and Dr. Rachel O’Malley, Environmental Studies, SJSU, assisted in identifying invertebrate orders. Dr. Dan Rosenberg, Oregon State University, and an anonymous reviewer helped greatly with the manuscript.

\section{Literature Cited}

ADAms, L.W. 1984. Small mammal use of an interstate highway median strip. Journal of Applied Ecology 21:175-178.

Arana, M., M.L. Ruiz-Luna, S. Santa Maria, and O. Ramirez. 2006. Population fluctuations of the house mouse in a Peruvian loma and the functional response of Burrowing Owls. Austral Ecology 31:956-963.

BLAIR, R.B. 1996. Land use and avian species diversity along an urban gradient. Ecological Applications 6:506-519.

Bock, C.E., K.T. Vierling, S.L. Haire, J.D. Boone, and W.W. Merkle. 2002. Patterns of rodent abundance on open-space grasslands in relation to suburban edges. Conservation Biology 16:1653-1658.

Bolger, D.T., A.C. Alberts, R.M. Sauvajot, P. Potenza, C. McCalvin, D. Tran, S. Mazzoni, and M.E. SOULÉ. 1997. Response of rodents to habitat fragmentation in coastal Southern California. Ecological Applications 7:552-563.

Bolger, D.T., A.V. Suarez, K.R. Crooks, S.A. Morrison, AND T.J. Case. 2000. Arthropods in urban habitat fragments in Southern California: area, age and edge effects. Ecological Applications 10:1230-1248.

Buchanan, J.T. 1996. A geographic analysis of the Burrowing Owl population in Santa Clara County, Cali- fornia. Master's thesis, San Jose State University, San Jose, CA.

Coulombe, H.N. 1971. Behavior and population ecology of the Burrowing Owl in the Imperial Valley of California. Condor 73:162-176.

DeSante, D.F., E.D. Ruhlen, and D.K. Rosenberg. 2004. Density and abundance of Burrowing Owls in the agricultural matrix of the Imperial Valley, California. Studies in Avian Biology-Series 27:116-119.

Dingle, H., T.A. Mosseau, And S.M. ScotT. 1990. Altitudinal variations in life cycle syndromes of the grasshopper, Melanoplus sanguinipes (F.). Oecologia 84:199-206.

Gervais, J.A., D.K. RosenberG, D.M. Fry, L. Trulio, and K.K. STURM. 2000. Burrowing Owls and agricultural pesticides: evaluation of residues and risks for three populations in California, USA. Environmental Toxicology and Chemistry 19:337-343.

Gleason, R.L., and T.H. Craig. 1979. Food habits of Burrowing Owls in southeastern Idaho. Great Basin Naturalist 39:274-276.

GLEason, R.S., AND D.R. Johnson. 1985. Factors influencing nesting success of Burrowing Owls in Southeastern Idaho. Great Basin Naturalist 45:81-84.

Green, G.A., And R.G. AnTHony. 1997. Ecological considerations for management of breeding Burrowing Owls in the Columbia Basin. Journal of Raptor Research 9:117-121.

Green, G.A., R.E. Fitzner, R.G. Anthony, and L.E. Rogers. 1993. Comparative diets of Burrowing Owls in Oregon and Washington. Northwest Science 67: 88-93.

HaLEY, K.L. 2002. The role of food limitation and predation on reproductive success of Burrowing Owls in Southern California. Master's thesis, Oregon State University, Corvallis, OR.

Hall, D.B., P.D. Greger, AND J.R. Rosier. 2009. Regional and seasonal diet of the Western Burrowing Owl in south central Nevada. Western North American Naturalist 69:1-8.

Handel, S.N., G.R. Robinson, W.F.J. Parsons, and J.H. MATTEI. 1997. Restoration of woody plants to capped landfills: root dynamics in an engineered soil. Restoration Ecology 5:178-186.

Haug, E.A., B.A. Millsap, and M.S. Martell. 1993. Burrowing Owl (Speotyto cunicularia). No. 61 in The Birds of North America. American Ornithologists' Union, Washington, DC, and the Academy of Natural Sciences, Philadelphia, PA.

Higgins, P.G. 2007. Prey base analysis of Burrowing Owls in urban Santa Clara County, California. Master's thesis, San Jose State University, San Jose, CA.

Holroyd, G.L., R. Rodriguez-Estrella, and S. ShefFIELD. 2001. Conservation of the Burrowing Owl in western North America: issues, challenges and recommendations. Journal of Raptor Research 35: 399-407.

Jameson, E.W., And H. Peeters. 2004. Mammals of California. University of California Press, Berkeley, CA. $440 \mathrm{pp}$.

Jones, C.A., AND C.N. BAXTER. 2004. Thomomys bottae. Mammalian Species 742:1-14.

Jones, Z.F., AND C.E. Bock. 2002. Conservation of grassland birds in an urbanizing landscape: a historical perspective. Condor 104:643-651.

Kays, R.W., AND D.E. Wilson. 2002. Mammals of North America. Princeton University Press, Princeton, NJ. 
Millsap, B.A., AND C. BEAR. 2000. Density and reproduction of Burrowing Owls along an urban development gradient. Journal of Wildlife Management 64:33-41.

Moulton, C.E., R.S. Brady, and J.R. Belthoff. 2005. A comparison of breeding season food habits of Burrowing Owls nesting in agricultural and nonagricultural habitat in Idaho. Journal of Raptor Research 39:429-438

Mrykalo, R.J., M.M. Grigion, and R.J. Sarno. 2009. A comparison of available prey and diet of Florida Burrowing Owls in urban and rural environments: a first study. Condor 111:556-559.

Plumpton, D.L., AND S.R. LuTz. 1993. Prey selection and food habits of Burrowing Owls in Colorado. Great Basin Naturalist 53:299-304.

Poulin, R.G., AND L.D. TodD. 2006. Nest and sex stage differences in the circadian foraging behaviors of nesting Burrowing Owls. Condor 108:856-864.

Powell, J.A., AND C.L. Hogue. 1979. California insects. University of California Press, Berkeley, CA. 398 pp.

Restani, M., L.R. Rau, and D.L. Flath. 2001. Nesting ecology of Burrowing Owls occupying black-tailed prairie dog towns in southeastern Montana. Journal of Raptor Research 35:296-303.

RosenberG, D.K., AND K.L. Haley. 2004. The ecology of Burrowing Owls in the agroecosystems of the Imperial Valley, California. Studies in Avian BiologySeries 27:120-135.

Soulé, M.E., A.C. Alberts, And C.T. Bolger. 1992. The effects of habitat fragmentation on chaparral plants and vertebrates. Oikos 63:39-47.
Strong, A.M., C.C. Rimme, and K.P. McFarland. 2004. Effect of prey biomass on reproductive success and mating strategy of Bicknelus Thrush (Catharus bicknelli), a polygynandrous songbird. Auk 121:446-451.

Thomsen, L. 1971. Behavior and ecology of Burrowing Owls on the Oakland Municipal Airport. Condor 73:177-192

Trulio, L.A. 1997. Burrowing Owl demography and habitat use at two urban sites in Santa Clara County, California. Journal of Raptor Research 9:84-89.

Trulio, L.A., AND D.A. ChromczaK. 2007. Burrowing Owl nesting success at urban and parkland sites in Northern California. Pages 115-122 in J.H. Barclay, K.W. Hunting, J.L. Lincer, and T.A. Roberts, editors, Proceedings of the California Burrowing Owl Symposium, November 2003. Bird Populations Monograph 1. Institute for Bird Populations and Albion Environmental, Inc., Point Reyes Station, CA.

WESEMann, T., AND M. Rowe. 1987. Factors influencing the distribution and abundance of Burrowing Owls in Cape Coral, Florida. Integrating Man and Nature in the Metropolitan Environment. Proceedings of the National Symposium on Urban Wildlife, Columbia, MD.

York, M.M., D.K. Rosenberg, and K.K. Sturm. 2002. Diet and food-niche breadth of Burrowing Owls (Athene cunicularia) in the Imperial Valley, California. Western North American Naturalist 62:280-287.

Received 14 July 2011 Accepted 26 April 2012 